\title{
Monoclonal antibodies as probes for detecting lipopolysaccharide expression on Escherichia coli from different growth conditions
}

\author{
David Nelson, Andrew J. Bathgate and Ian R. Poxton* \\ Department of Medical Microbiology, University of Edinburgh Medical School, Teviot Place, Edinburgh EH8 $9 A G, U K$
}

(Received 10 June 1991; revised 22 August 1991; accepted 16 September 1991)

\begin{abstract}
Monoclonal antibody (mAb) probes were used to investigate the expression of lipopolysaccharide (LPS) on four Escherichia coli strains, grown under a variety of conditions in batch culture which mimicked some of the in vivo environmental conditions of an infected host. Techniques of silver staining, immunoblotting, whole cell ELISA and flow cytometry were all used to monitor the expression of LPS on the bacteria and the binding of the anti-LPS mAbs. Growth in heat-inactivated sheep serum and magnesium-depleted conditions demonstrated increased expression of LPS core and subsequent increased binding of anti-core mAbs. Magnesium-depleted conditions also resulted in decreased production of $\mathrm{O}$-polysaccharide material. Iron-depleted bacteria showed only minor changes in LPS expression, although increased binding of anti-core $\mathbf{m A b s}$ was observed. Nitrogen-deficient/high-carbon conditions, chosen to promote capsule production, resulted in increased expression of $\mathbf{O}$-polysaccharide and decreased binding of anti-core mAbs.
\end{abstract}

\section{Introduction}

The potential of antibody therapy for the prevention and treatment of Gram-negative sepsis and endotoxaemia with anti-lipopolysaccharide (LPS) antibodies has been intensively investigated recently (Dunn et al., 1986). Much attention has been focussed on the production and characterization of monoclonal antibodies (mAbs) to common epitopes of endotoxin in the LPS core. There are many reports in the literature of the development of such mAbs (Ziegler et al., 1991; de Jongh-Leuvenink, 1990; Mayoral \& Dunn, 1990; Pollack et al., 1989). The therapeutic potential of anti-LPS mAbs is, however, open to much debate (Heumann et al., 1991; Aydintung et al., 1989; Chia et al., 1989). Concern exists as to whether it is possible for these antibodies to bind to sites deep within the LPS molecule, either when the LPS is bound to the bacterium or to host components such as high density lipoprotein and endothelial surfaces, or 'free' in micelles. A further complication exists by which the heterogeneity of O-polysaccharide chain length and degree of substitution of the LPS core may affect antibody accessibility (Gigliotti \& Shenep, 1985).

We have shown recently that it is possible, with a combination of ELISA and flow cytometry, to use monoclonal antibodies to detect LPS expression on whole bacteria (Neison et al., 1990). Results showed, however, that although anti-O-polysaccharide mAbs could readily be observed binding to bacteria by both techniques, anti-core mAbs could be shown to bind significantly only by the sensitive ELISA and not by flow cytometry.

It is now well recognized that the growth environment of bacteria greatly influences the phenotypic expression of surface characters (Smith et al., 1991; McGroarty \& Rivera, 1990; Kelly et al., 1989; Morse et al., 1983). This study attempts to investigate with $\mathrm{mAb}$ probes the expression of LPS on bacteria cultured in conditions which mimic those in vivo.

\section{Methods}

Bacteria. Four strains of Escherichia coli were kindly supplied by $\mathrm{Dr}$ A. S. Cross, Walter Reed Institute for Army Research, Washington, DC, USA. They consisted of two clinical isolates $(018: \mathrm{K} 1$ and $06: \mathrm{K} 5$ serotypes) together with two isogenic mutants from the 018 parent: a non-capsulate mutant $\left(\mathrm{O} 18: \mathrm{K}^{-}\right)$and a rough mutant $(\mathrm{O} 18: \mathrm{Krf})$.

Culture conditions. The following growth media were used. (a) Nutrient broth (Gibco), filter-sterilized. (b) Magnesium-depleted medium. This was prepared as a modification of the Malka minimal medium of Robert-Gero et al. (1970) as follows: solution A, $\mathrm{Na}_{2} \mathrm{HPO}_{4}$ (73.4 $\left.\mathrm{mg} \mathrm{ml}^{-1}\right), \mathrm{KH}_{2} \mathrm{PO}_{4}\left(32.4 \mathrm{mg} \mathrm{ml}^{-1}\right)$; solution $\mathrm{B}, \mathrm{MgSO}_{4} .7 \mathrm{H}_{2} \mathrm{O}$ $\left(20.5 \mathrm{mg} \mathrm{ml}^{-1}\right)$; solution $\mathrm{C}, 20 \%(\mathrm{w} / \mathrm{v})$ glucose; solution $\mathrm{D}$, $\mathrm{FeSO}_{4} .7 \mathrm{H}_{2} \mathrm{O}\left(1.83 \mathrm{mg} \mathrm{ml}^{-1}\right)$ in sterile distilled water to which one drop of concentrated hydrochloric acid was added; solution $\mathrm{E}\left(\mathrm{NH}_{4}\right)_{2} \mathrm{SO}_{4}$ $\left(50.0 \mathrm{mg} \mathrm{ml}^{-1}\right)$. All chemicals were from BDH. Solutions were prepared with sterile distilled water and were filter sterilized. All 
solutions except $\mathrm{C}$ were stored over chloroform. To prepare 1 litre of Malka, $20 \mathrm{ml} \mathrm{A}, 20 \mathrm{ml} \mathrm{B}, 20 \mathrm{ml} \mathrm{C}, 1 \mathrm{ml} \mathrm{D}$ and $20 \mathrm{ml} \mathrm{E}$ were added to $919 \mathrm{ml}$ of sterile distilled water. Magnesium-depleted medium containing $0.17 \mathrm{mmol}^{-1}$ was prepared by the addition of only a $1 \% \mathrm{vol}$. $(0.2 \mathrm{ml})$ of solution B as used for the standard minimal medium. (c) Nitrogen-deficient/high-carbon medium. This was prepared following the method of Sutherland \& Wilkinson (1965) and contained: $1 \mathrm{~g}$ yeast extract (Oxoid); $1 \mathrm{~g}$ Casamino acids (Difco technical grade); $10 \mathrm{~g}$ $\mathrm{Na}_{2} \mathrm{HPO}_{4} ; 3 \mathrm{~g} \mathrm{KH}_{2} \mathrm{PO}_{4} ; 0.2 \mathrm{~g} \mathrm{MgSO}_{4} .7 \mathrm{H}_{2} \mathrm{O} ; 11 \mathrm{~g} \mathrm{~K} \mathrm{SO}_{4} ; 1 \mathrm{~g} \mathrm{NaCl}$; $0.01 \mathrm{~g} \mathrm{CaCl}_{2} .2 \mathrm{H}_{2} \mathrm{O}$; and $0.01 \mathrm{~g} \mathrm{FeSO}_{4} .7 \mathrm{H}_{2} \mathrm{O}$. The volume was made up to $1000 \mathrm{ml}$ with sterile distilled water and autoclaved. To this, $20 \%$ $(w / v)$ filter-sterilized glucose was added to give a final concentration of $2 \%(\mathrm{w} / \mathrm{v})$ glucose. (d) Iron-depleted medium. This was prepared by the addition of $150 \mu \mathrm{mol} 2,2^{\prime}$-dipyridyl $1^{-1}$ to Gibco nutrient broth. (e) Heat-inactivated sheep serum (obtained from the Moredun Research Institute, Edinburgh, UK): the serum was filter-sterilized $(0.45 \mu \mathrm{m}$ pore size) and heat-inactivated at $56{ }^{\circ} \mathrm{C}$ for $60 \mathrm{~min}$ and stored at $-20^{\circ} \mathrm{C}$.

Exponential phase starter cultures were prepared by growth in nutrient broth at $37^{\circ} \mathrm{C}$ for $4 \mathrm{~h}$ before harvesting and washing twice in phosphate-buffered saline (PBS; $0 \cdot 15 \mathrm{M}-\mathrm{NaCl}, 50 \mathrm{~mm}$-potassium phosphate buffer), $\mathrm{pH} 7 \cdot 4$. A $1 \%$ inoculum was added to each growth medium. Cultures were grown at $37^{\circ} \mathrm{C}$ in $100 \mathrm{ml}$ of each medium to early stationary phase in an orbital incubator prior to harvesting and washing as above.

Monoclonal antibodies. mAbs were prepared by fusing spleen cells from immune BALB/c mice with NS-O myeloma cells by standard techniques (Kipps \& Hertzenberg, 1986). The reactivity of the mAbs was determined by the LPS-polymyxin ELISA method of Scott \& Barclay (1987) as described by Nelson et al. (1990). Full details of the immunization of mice, selection of hybridomas and characterization of $\mathrm{mAbs}$ are to be published elsewhere. Three mAbs with known specificities in LPS-polymyxin ELISA were selected for this study: $\mathrm{mAb} \mathrm{O}-1$, specific for $\mathrm{O} 18 \mathrm{O}$-antigen, and two cross-reactive anti-core $\mathrm{mAbs}(\mathrm{C}-1$ and $\mathrm{C}-2)$, reactive to either core not substituted with $\mathrm{O}$ antigen (C-1) or to both substituted and unsubstituted core material (C2) (for more details see Nelson et al., 1990). Supernatant fluids of hybridoma cell cultures grown in RPMI 1640 supplemented with $5 \%$ $(\mathrm{v} / \mathrm{v})$ foetal calf serum in $150 \mathrm{~cm}^{2}$ flasks were used throughout. Cell cultures were grown to maximum cell density and harvested at $50 \%$ cell viability. These three hybridomas gave yields of approximately $50 \mu \mathrm{g}$ $\mathrm{ml}^{-1}$.

Preparation of LPS. LPS was prepared from whole washed bacteria by the proteinase K method of Hitchcock \& Brown (1983) as described by Hancock \& Poxton (1988). For each growth condition the density of washed bacteria was adjusted to an $\mathrm{OD}_{525}$ of 0.5 prior to proteinase $\mathrm{K}$ treatment. This allowed direct comparison of cells from each growth medium.

PAGE. PAGE was performed on $14 \%(\mathrm{w} / \mathrm{v})$ acrylamide slab gels with the Laemmli buffer system (Laemmli, 1970), except SDS was omitted from the stacking and separating buffers. Samples $(10 \mu \mathrm{l}$ for silver stain, or $20 \mu \mathrm{l}$ for immunoblotting) of the proteinase K LPS extracts were loaded onto the gels. The LPS separating gels were stained with silver by a method developed by Tsai \& Frasch (1982), as modified by Hancock \& Poxton (1988).

Immunoblot transfer. LPS separated by PAGE was electroblotted to nitrocellulose by the method of Towbin et al. (1979) as described by Hancock \& Poxton (1988) with Bio-Rad buffers and substrate. Nitrocellulose membrane of $0.2 \mu \mathrm{m}$ pore size was obtained from Schleicher and Schuell and an anti-mouse IgG-horseradish-peroxidase conjugate used (ICN). Antibody culture supernates were diluted 1 in 10 .
Diluents and buffers used in ELISA. (1) Coating buffer consisted of $0.05 \mathrm{M}$-carbonate/bicarbonate, $\mathrm{pH}$ 9.6. (2) Post-coat buffer consisted of PBS ( $\mathrm{pH} 7 \cdot 2$ ) containing $2 \%(\mathrm{w} / \mathrm{v}$ ) bovine serum albumin (BSA) (ICN). (3) Wash buffer consisted of PBS containing $0.05 \%(v / v)$ Tween 20. (4) Dilution buffer consisted of PBS containing $0.05 \%(\mathrm{v} / \mathrm{v})$ Tween 20 , $0.5 \%$ BSA and $4 \%(\mathrm{w} / \mathrm{v})$ polyethylene glycol 6000 (Sigma).

All solutions contained $0.02 \%$ sodium azide.

ELISA procedure. ELISA strips (Immuno module Polysorp F8, Nunc) were coated with washed bacteria $(100 \mu l$ per well) after measuring the $\mathrm{OD}_{540}$ and diluting with coating buffer to a concentration of $2 \times 10^{7}$ cells $\mathrm{ml}^{-1}$. Coating was promoted by centrifugation at $630 \mathrm{~g}$ for $4 \mathrm{~min}$ and leaving overnight at room temperature. Plates were washed four times in wash buffer, before post-coating with post-coat buffer at $100 \mu \mathrm{l}$ per well overnight at room temperature. After further washing, plates were rinsed in distilled water and stored at $-20{ }^{\circ} \mathrm{C}$ until used. mAb supernatant fluids were diluted $I$ in $10,40,160$ and 640 in dilution buffer and added to coated microplates at $100 \mu 1$ per well in triplicate. Plates were incubated at $37^{\circ} \mathrm{C}$ for $90 \mathrm{~min}$ before washing four times with wash buffer. Urease-conjugated sheep anti-mouse Ig (SeraLab) was diluted $I$ in 500 , added at $100 \mu \mathrm{l}$ per well and plates were incubated for a further $90 \mathrm{~min}$ at $37^{\circ} \mathrm{C}$. Plates were washed four times and rinsed in distilled water before urease substrate (SeraLab) at $100 \mu$ ] per well was added. Plates were incubated for $60 \mathrm{~min}$ at room temperature and reactions stopped by adding $1 \%(\mathrm{w} / \mathrm{v})$ thimerosal (Sigma) in distilled water $(20 \mu \mathrm{l}$ per well). The $\boldsymbol{A}$ of wells was read on an automated microplate reader Titertek Multiscan (MC, Flow Laboratories). Final results were expressed after subtraction of the absorbance readings of negative control wells (coated with BSA post-coat only) for each mAb.

Flow cytometry. Flow cytometry was based on the method described by Nelson et al. (1990). Briefly, washed cultures of bacteria were resuspended to a concentration of about $1 \times 10^{8}$ cells $\mathrm{ml}^{-1}$. Pellets from $1 \mathrm{ml}$ were resuspended in $1 \mathrm{ml}$ of $\mathrm{mAb}$ culture supernate, diluted 1 in 10 in dilution buffer (see ELISA methodology), and incubated for $60 \mathrm{~min}$ at $37^{\circ} \mathrm{C}$. After washing twice in PBS, $0.5 \mathrm{ml}$ sheep FITC-conjugated anti-mouse IgG (ICN), diluted 1 in 100 in dilution buffer, was added and incubated for $60 \mathrm{~min}$ at $37^{\circ} \mathrm{C}$. After further washing in PBS, the pellet was resuspended in PBS containing $0.5 \%$ formaldehyde. Samples were diluted 1 in 50 in PBS and analysed in an EPICS ' $\mathrm{C}$ ' (Coulter Electronics) flow cytometer with a $5 \mathrm{~W}$ argon ion laser operating at $500 \mathrm{~mW}$ and exciting at $488 \mathrm{~nm}$. A total of 50000 cells at 500 cells s$^{-1}$ were passed through the beam from a $76 \mu \mathrm{m}$ tip. Background noise and clumps of cells were excluded by a gate on the log forward angle light scatter. The percentage of cells exhibiting positive staining was calculated with the EPICS 'Stat Pack' program.

\section{Results}

\section{Silver-staining and immunoblot analysis of LPS}

Figs 1-3 represent silver-stained PAGE profiles of LPS and their corresponding immunoblots from four $E$. coli strains grown under different batch culture growth conditions. The three smooth strains showed the characteristic ladder pattern, each step up representing LPS substituted with a progressively increasing number of $\mathrm{O}$ polysaccharide repeating oligosaccharide units. These were missing from the rough mutant. The effect of each growth condition on the expression of LPS was compared with nutrient broth. Silver-stained profiles of LPS 
Table 1. ELISA results of the three anti-LPS $m$ Abs titrated against whole cells of $E$. coli $\mathrm{O} 18: \mathrm{Kl}$ and $\mathrm{O} 18: \mathrm{K}^{-}$grown in five different media

\begin{tabular}{|c|c|c|c|c|c|}
\hline \multirow[b]{3}{*}{$\mathrm{mAb}$} & \multirow{3}{*}{$\begin{array}{l}\text { Growth } \\
\text { medium }\end{array}$} & \multicolumn{4}{|c|}{ ELISA results } \\
\hline & & \multicolumn{2}{|c|}{$A_{\max } *$} & \multicolumn{2}{|c|}{$D_{50} \dagger$} \\
\hline & & $018: \mathrm{K} 1$ & $018: \mathrm{K}^{-}$ & $018: \mathrm{K} 1$ & $018: \mathrm{K}^{-}$ \\
\hline \multirow[t]{5}{*}{$0-1$} & Nutrient broth & $1 \cdot 26$ & $1 \cdot 34$ & 120 & 260 \\
\hline & $\begin{array}{l}\text { Nitrogen-deficient/ } \\
\text { high-carbon }\end{array}$ & $1 \cdot 31$ & $1 \cdot 33$ & 145 & 280 \\
\hline & Iron-depleted & $1 \cdot 19$ & 1.24 & 105 & 110 \\
\hline & Serum & 1.31 & 1.41 & 150 & 210 \\
\hline & Magnesium-depleted & $1 \cdot 39$ & $1 \cdot 19$ & 120 & 75 \\
\hline \multirow[t]{5}{*}{$C-1$} & Nutrient broth & 0.32 & 0.55 & 37 & 36 \\
\hline & $\begin{array}{l}\text { Nitrogen-deficient/ } \\
\text { high-carbon }\end{array}$ & $0 \cdot 17$ & $0 \cdot 20$ & 23 & 40 \\
\hline & Iron-depleted & 0.65 & 0.82 & 32 & 90 \\
\hline & Serum & 0.97 & $1 \cdot 15$ & 140 & 180 \\
\hline & Magnesium-depleted & 0.88 & $1 \cdot 18$ & 66 & 120 \\
\hline \multirow[t]{5}{*}{$C-2$} & Nutrient broth & 0.45 & 0.51 & 40 & 40 \\
\hline & $\begin{array}{l}\text { Nitrogen-deficient/ } \\
\text { high-carbon }\end{array}$ & 0.08 & $0 \cdot 23$ & 50 & 60 \\
\hline & Iron-depleted & 0.62 & 0.98 & 56 & 36 \\
\hline & Serum & 0.73 & $1 \cdot 24$ & 270 & 370 \\
\hline & Magnesium-depleted & 0.87 & 1.01 & 34 & 200 \\
\hline
\end{tabular}

* Maximum $A_{590}$ for the 1 in 10 dilution (first dilution) of antibody.

$\dagger$ The dilution factor when the absorbance is $50 \%$ of the maximum.

of proteinase-K-digested whole cells grown in nutrient broth, iron-depleted and nitrogen-deficient/glucose-enriched media are shown in Fig. 1(a). LPS from irondepleted cells showed only minor changes compared to the LPS from cells grown in nutrient broth, whilst cells grown in a nitrogen-deficient/glucose-enriched medium showed an increased expression of both mid-range and high molecular mass bands. Immunoblotting of transblotted gels against mAb O-1 (Fig. $1 b$ ), demonstrates the specificity for the $\mathrm{O}$-antigen of $E$. coli $\mathrm{O} 18$ and small amounts of high molecular mass $\mathrm{O}$-antigen leaking from the rough mutant of 018 . The immunoblot again illustrates greater expression of O-antigen as well as an overall increase in O-polysaccharide chain length for cells grown under nitrogen deficiency. Probing with $\mathrm{C}-2$, an anti-core $\mathrm{mAb}$ reactive against both substituted and unsubstituted core material showed no significant differences between growth conditions (Fig. 1c). PAGE of LPS from the four $E$. coli strains grown in magnesiumdepleted medium showed a significant increase in the expression of unsubstituted core-glycolipid material and other low molecular mass bands (Fig. 2a). Immunoblotting with $\mathrm{mAb} \mathrm{O}-1$ showed similar expression of $\mathrm{O}-$ antigen for both nutrient broth and magnesium-depleted conditions (Fig. 2b), whilst probing with mAb C-2 further highlighted a pronounced increase in core LPS (Fig. 2c). Growth in sheep serum resulted in greater expression of both the fast migrating core region, as well as high molecular mass O-antigen-bearing molecular species of the smooth strains compared to growth in nutrient broth (Fig. $3 a$ ). Immunoblot analysis with $\mathrm{mAb}$ $C-1$, reactive only with unsubstituted core material, and C-2, demonstrated better expression of predominantly rough form LPS when grown in serum (Fig. $3 b, c$ ).

\section{ELISA on whole bacteria}

The binding activities of the three $\mathrm{mAbs}$ to whole cells of E. coli strains $\mathrm{O} 18: \mathrm{K} 1$ and $\mathrm{O} 18: \mathrm{K}^{-}$, cultured under various growth conditions are summarized in Table 1 . To give an indication of the amount of antibody bound by bacteria from each growth condition, the $A_{\max }$ (maximum $A_{590}$ reading obtained for the first dilution of the $\mathrm{mAb})$ should be compared. The affinity which each antibody has for the bacteria from the various growth conditions is compared by calculating the $D_{50}$ for each dilution curve, that is the dilution factor required to give the $50 \%$ value of the maximum absorbance reading. No significant differences in binding of the anti-O $\mathrm{mAb}$ to E. coli $\mathrm{O} 18: \mathrm{K} 1$ were detected for the different growth conditions. However, at high antibody dilutions $(>1$ in 160 ) the non-capsulate mutant $E$. coli $\mathrm{O} 18: \mathrm{K}^{-}$showed a significant decrease in binding of $\mathrm{mAb} O-1$ to cells grown under both iron and magnesium limitation (data not shown). On comparing the $D_{50}$ values, the 018 noncapsulate strain showed stronger affinity for both anti- 
(a)

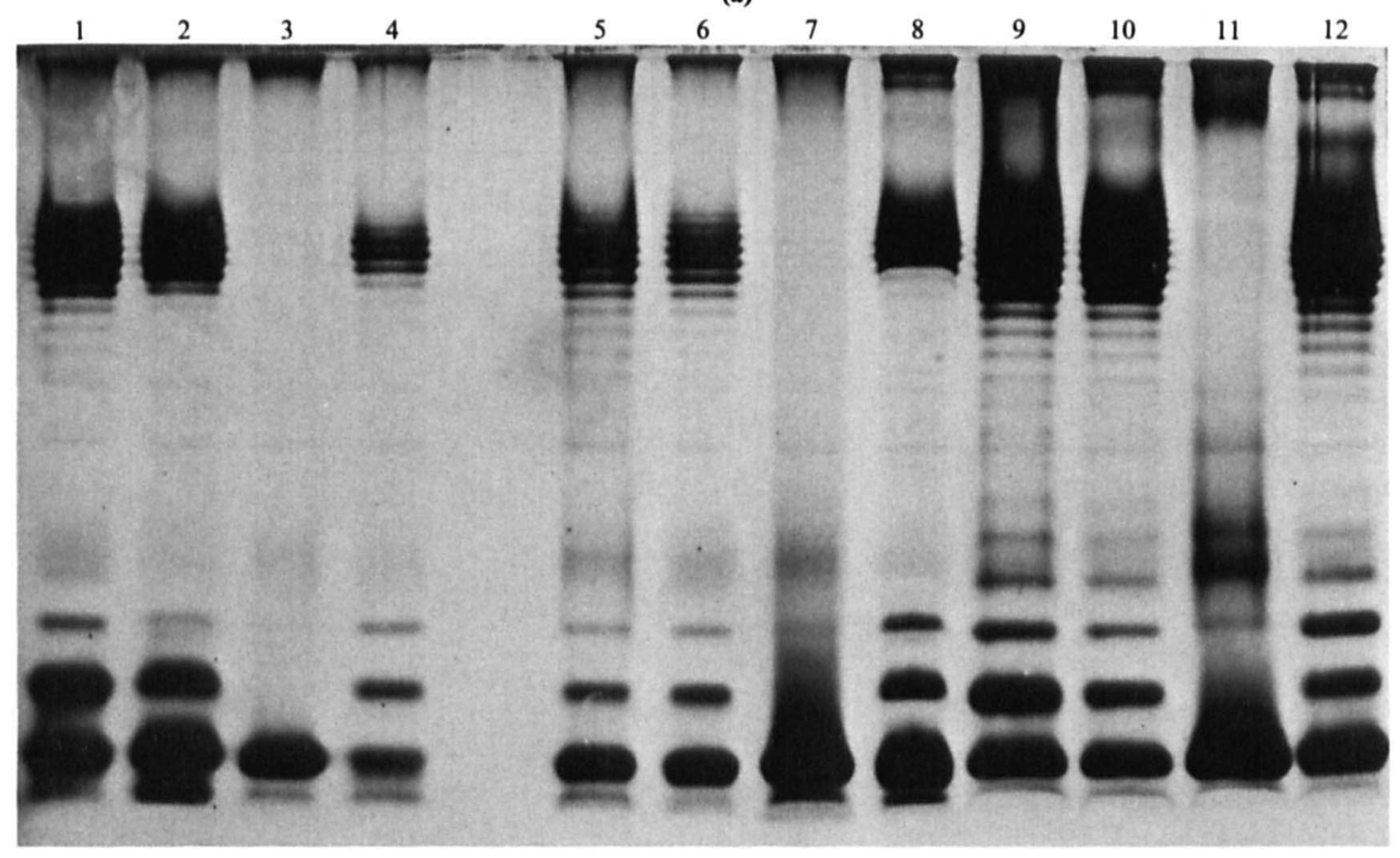

(b)

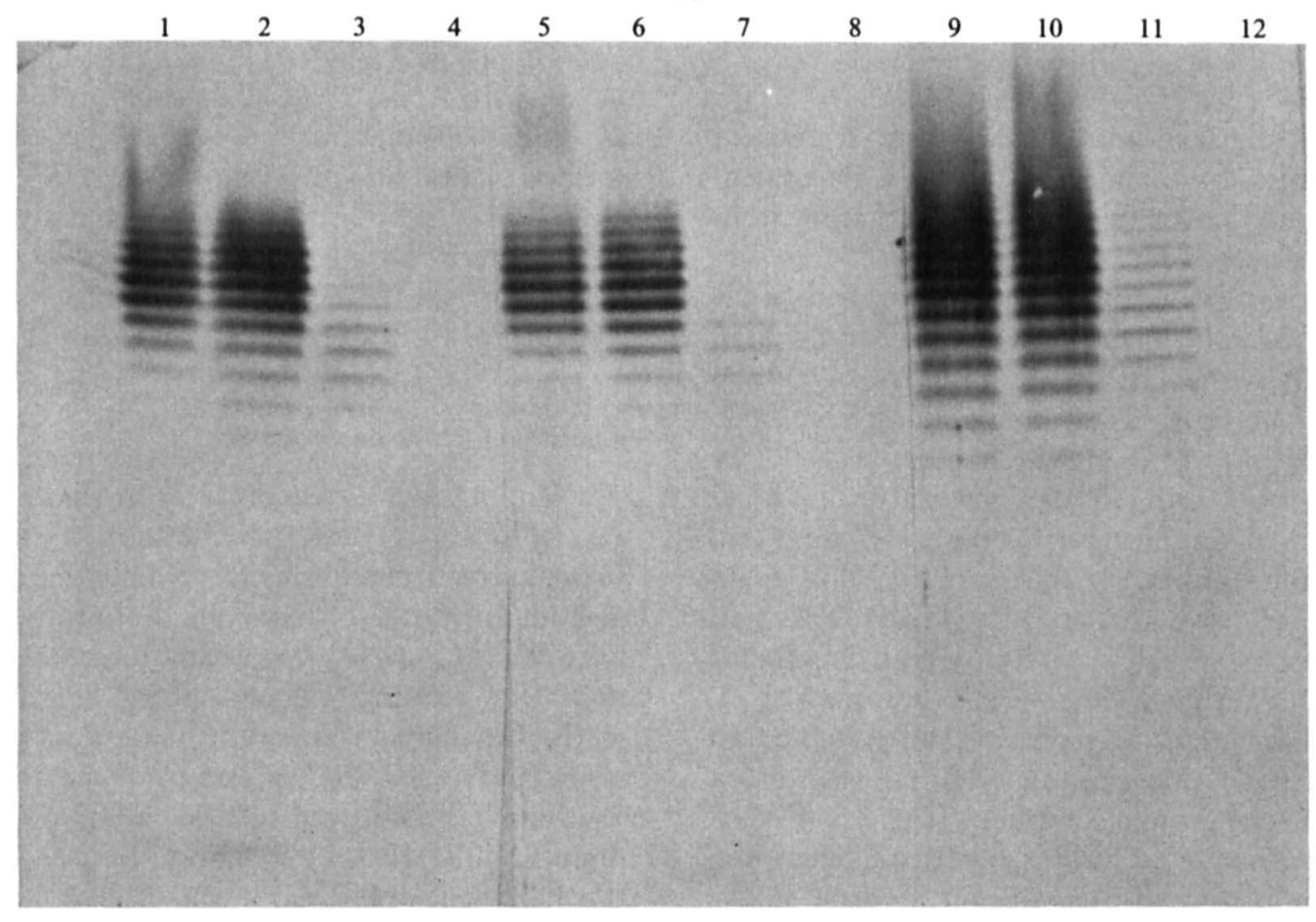

core and the anti-O mAbs compared to its capsulate parent when grown under most growth conditions, the exceptions being the magnesium-depleted medium for the anti-O $\mathrm{mAb}$ and the iron-depleted medium for $\mathrm{mAb}$ C-2. Growth of both $E$. coli strains in the nitrogen- deficient/glucose-enriched medium resulted in much lower binding of the two anti-core $\mathrm{mAbs}$ compared to growth in nutrient broth. However, significant increases in $A_{590}$ were observed when both strains were grown in serum and magnesium limitation and probed with mAbs 
(c)

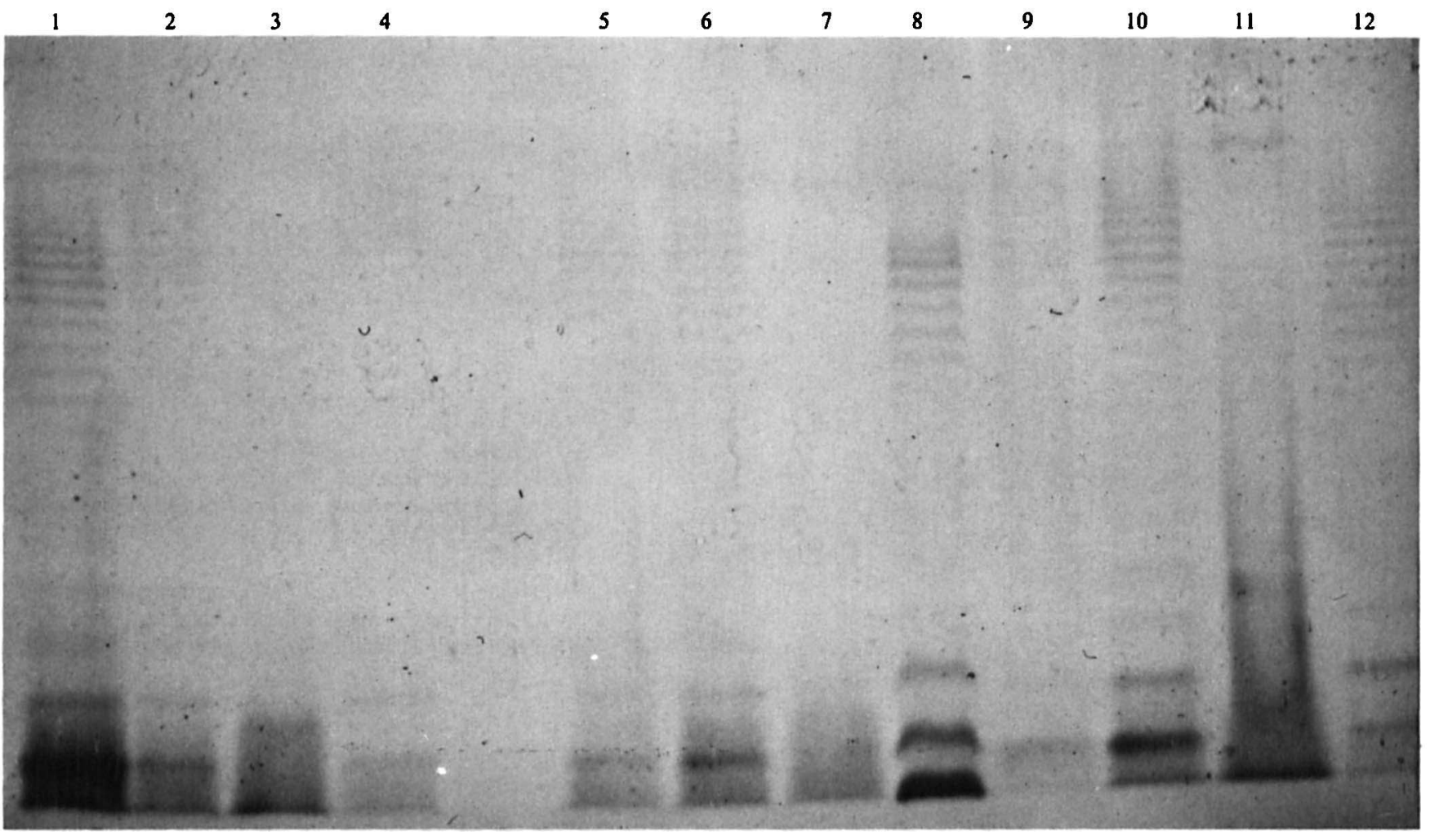

Fig. 1 (a) Silver-stained LPS profiles of proteinase $\mathrm{K}$ whole cell digests of four $E$. coli strains (O18:K1, O18:K-, O18:Krf and O6:K5) separated by PAGE $(14 \%, \mathrm{w} / \mathrm{v}$, acrylamide). $(b, c)$ Immunoblots of the four $E$. coli strains transferred to nitrocellulose paper and probed with $(b)$ an anti-O18 specific $\mathrm{mAb}, 0-1$, and $(c)$ a core-specific $\mathrm{mAb}, \mathrm{C}-2$. Tracks 1-4, 5-8 and 9-12 represent the four $E$. coli strains grown to early stationary phase in nutrient broth, an iron-depleted medium and a nitrogen-deficient medium respectively.

Table 2. Flow cytometric analysis of anti-LPS mAb binding to whole cells of four E. coli strains grown under different conditions.

Percentage values represent the mean positive fluorescence of bacteria above background levels from three separate experiments. ND, Not done.

\begin{tabular}{|c|c|c|c|c|c|}
\hline \multirow[b]{2}{*}{$\mathrm{mAb}$} & \multirow{2}{*}{$\begin{array}{l}\text { Growth } \\
\text { medium }\end{array}$} & \multicolumn{4}{|c|}{$\begin{array}{l}\text { Percentage of cells (mean } \pm \text { SD) } \\
\text { showing positive fluorescence }\end{array}$} \\
\hline & & $018: K 1$ & $018: \mathrm{K}^{-}$ & O18:Krf & O6:K5 \\
\hline \multirow[t]{2}{*}{$0-1$} & $\begin{array}{l}\text { Nutrient broth } \\
\text { Nitrogen-deficient/ } \\
\text { high-carbon }\end{array}$ & $\begin{array}{l}70( \pm 19) \\
73( \pm 10)\end{array}$ & $\begin{array}{l}62( \pm 14) \\
68( \pm 7)\end{array}$ & $\begin{array}{r}2( \pm 1) \\
13( \pm 6)\end{array}$ & $\begin{array}{l}\text { ND } \\
\text { ND }\end{array}$ \\
\hline & $\begin{array}{l}\text { Iron-depleted } \\
\text { Serum } \\
\text { Magnesium-depleted }\end{array}$ & $\begin{array}{l}74( \pm 6) \\
68( \pm 15) \\
49( \pm 9)\end{array}$ & $\begin{array}{l}50( \pm 3) \\
67( \pm 8) \\
39( \pm 9)\end{array}$ & $\begin{array}{l}3( \pm 1) \\
8( \pm 1) \\
7( \pm 0)\end{array}$ & $\begin{array}{l}\text { ND } \\
\text { ND } \\
\text { ND }\end{array}$ \\
\hline \multirow[t]{2}{*}{$C-1$} & $\begin{array}{l}\text { Nutrient broth } \\
\text { Nitrogen-deficient/ } \\
\text { high-carbon }\end{array}$ & $\begin{array}{l}3( \pm 1) \\
2( \pm 0)\end{array}$ & $\begin{array}{l}3( \pm 2) \\
2( \pm 1)\end{array}$ & $\begin{array}{l}68( \pm 11) \\
56( \pm 12)\end{array}$ & $\begin{array}{l}7( \pm 1) \\
1( \pm 0)\end{array}$ \\
\hline & $\begin{array}{l}\text { Iron-depleted } \\
\text { Serum } \\
\text { Magnesium-depleted }\end{array}$ & $\begin{array}{l}10( \pm 7) \\
28( \pm 16) \\
21( \pm 4)\end{array}$ & $\begin{array}{l}7( \pm 4) \\
61( \pm 11) \\
24( \pm 5)\end{array}$ & $\begin{array}{l}66( \pm 7) \\
43( \pm 14) \\
75( \pm 13)\end{array}$ & $\begin{array}{c}7( \pm 3) \\
26( \pm 12) \\
18( \pm 8)\end{array}$ \\
\hline \multirow[t]{2}{*}{$C-2$} & $\begin{array}{l}\text { Nutrient broth } \\
\text { Nitrogen-deficient/ } \\
\text { high-carbon }\end{array}$ & $\begin{array}{l}2( \pm 1) \\
2( \pm 0)\end{array}$ & $\begin{array}{l}6( \pm 1) \\
3( \pm 1)\end{array}$ & $\begin{array}{l}26( \pm 11) \\
16( \pm 6)\end{array}$ & $\begin{array}{l}3( \pm 2) \\
2( \pm 1)\end{array}$ \\
\hline & $\begin{array}{l}\text { Iron-depleted } \\
\text { Serum } \\
\text { Magnesium-depleted }\end{array}$ & $\begin{array}{r}3( \pm 2) \\
16( \pm 5) \\
12( \pm 4)\end{array}$ & $\begin{array}{l}8( \pm 3) \\
34( \pm 11) \\
18( \pm 2)\end{array}$ & $\begin{array}{l}20( \pm 5) \\
20( \pm 12) \\
28( \pm 7)\end{array}$ & $\begin{array}{l}14( \pm 9) \\
32( \pm 8) \\
10( \pm 2)\end{array}$ \\
\hline
\end{tabular}




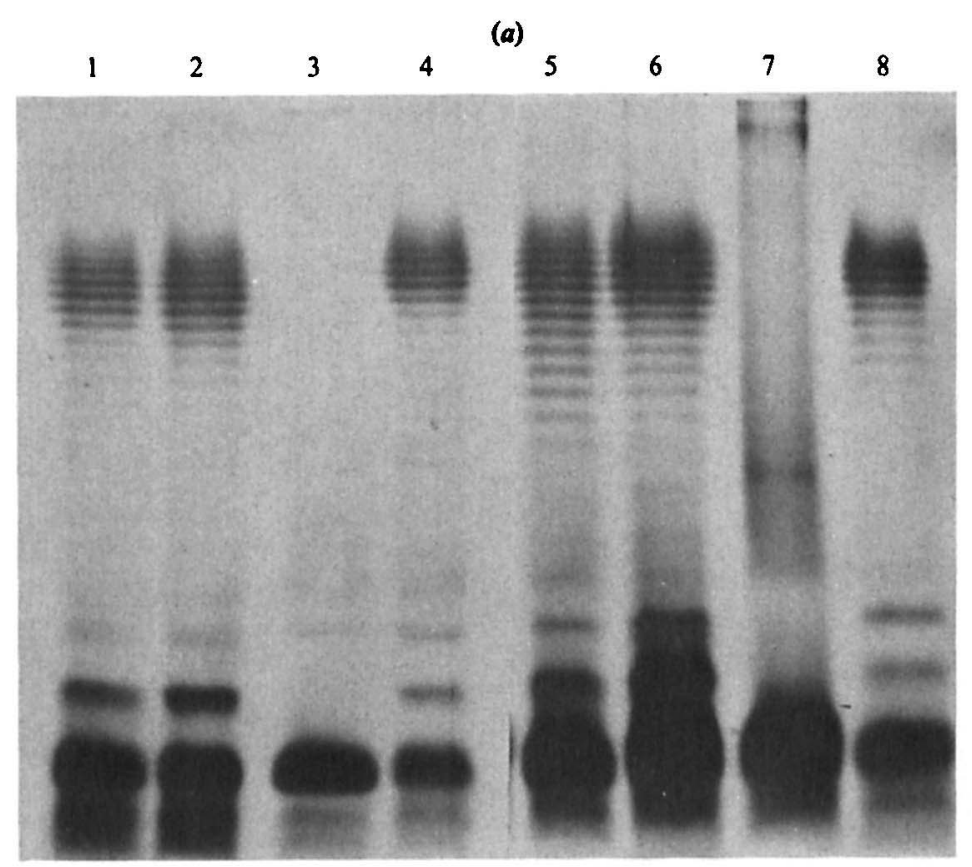

(b)

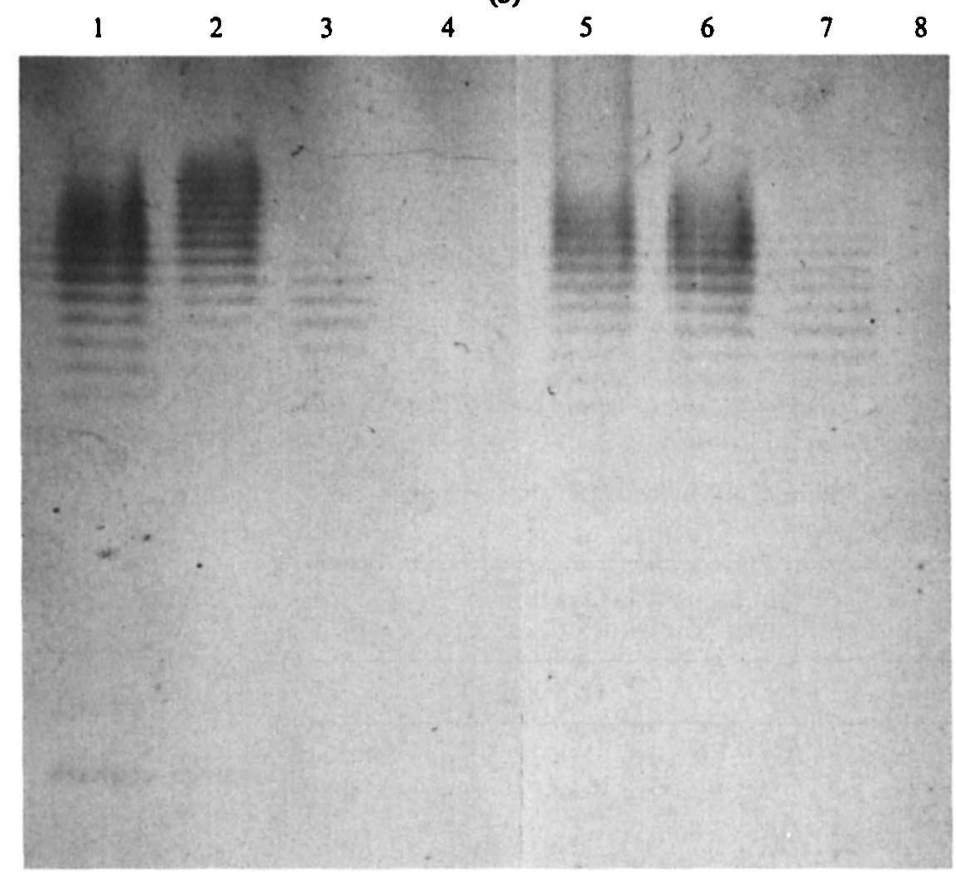

Fig. 2. (a) Silver-stained LPS profiles of proteinase $\mathrm{K}$ whole cell digests of four $E$. coli strains $(018: \mathrm{Kl}$, $\mathrm{O} 18: \mathrm{K}^{-}, \mathrm{O} 18: \mathrm{Krf}$ and $\left.\mathrm{O6}: \mathrm{K} 5\right)$ separated by PAGE $(14 \%, w / v$, acrylamide $) .(b, c)$ Immunoblots of the four $E$. coli strains transferred to nitrocellulose paper and probed with $(b)$ an $0-18$ specific $\mathrm{mAb}, \mathrm{O}-1$, and (c) a core-specific mAb, C-2. Tracks $1-4$ and 5-8 represent the four $E$. coli strains grown to early stationary phase in nutrient broth and a magnesiumdepleted medium respectively.

(c)

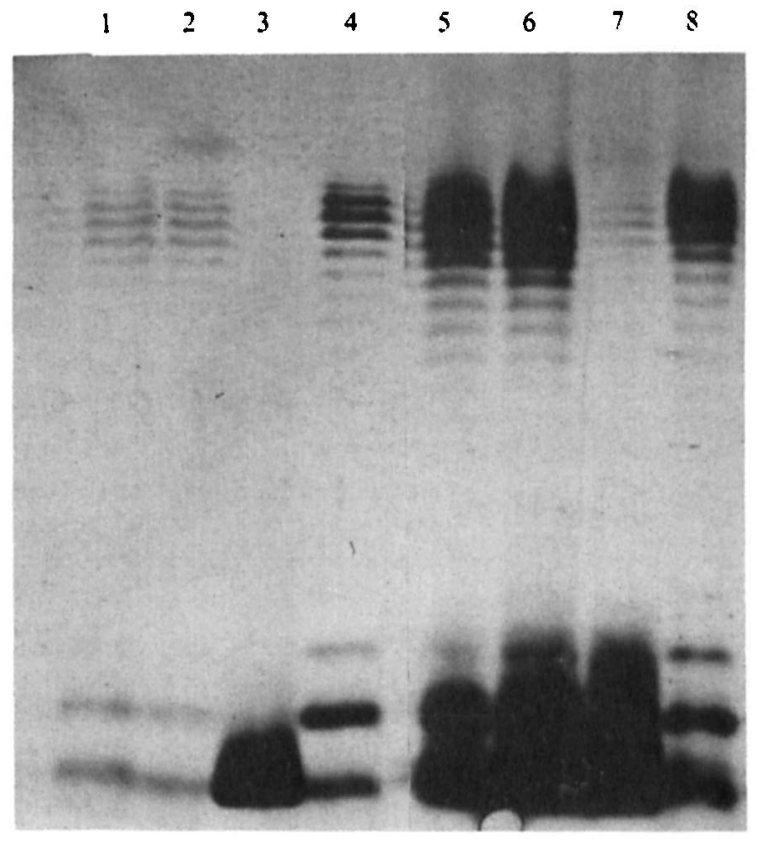

C-1 and C-2. A similar, yet slightly lower increase in binding of anti-core mAbs was seen for growth under iron-limitation compared to nutrient broth.

\section{Flow cytometric analysis}

The effect of growth conditions on the expression of LPS on whole bacteria was also investigated by flow cytometry. Flow cytometric profiles, which relate to the intensity of fluorescence signal (i.e. antibody binding to bacteria), were obtained consistently in three separate experiments. Examples of representative profiles are illustrated in Fig. 4(a,b). Histograms representing interaction of the $\mathrm{O} 18$-specific $\mathrm{mAb}, \mathrm{O}-1$ and cells grown in nutrient broth and magnesium-depleted medium are shown in Fig. 4(a). A 45\% decrease in magnesiumdepleted bacteria exhibiting positive fluorescence above background levels compared to nutrient broth cells was 
(a)

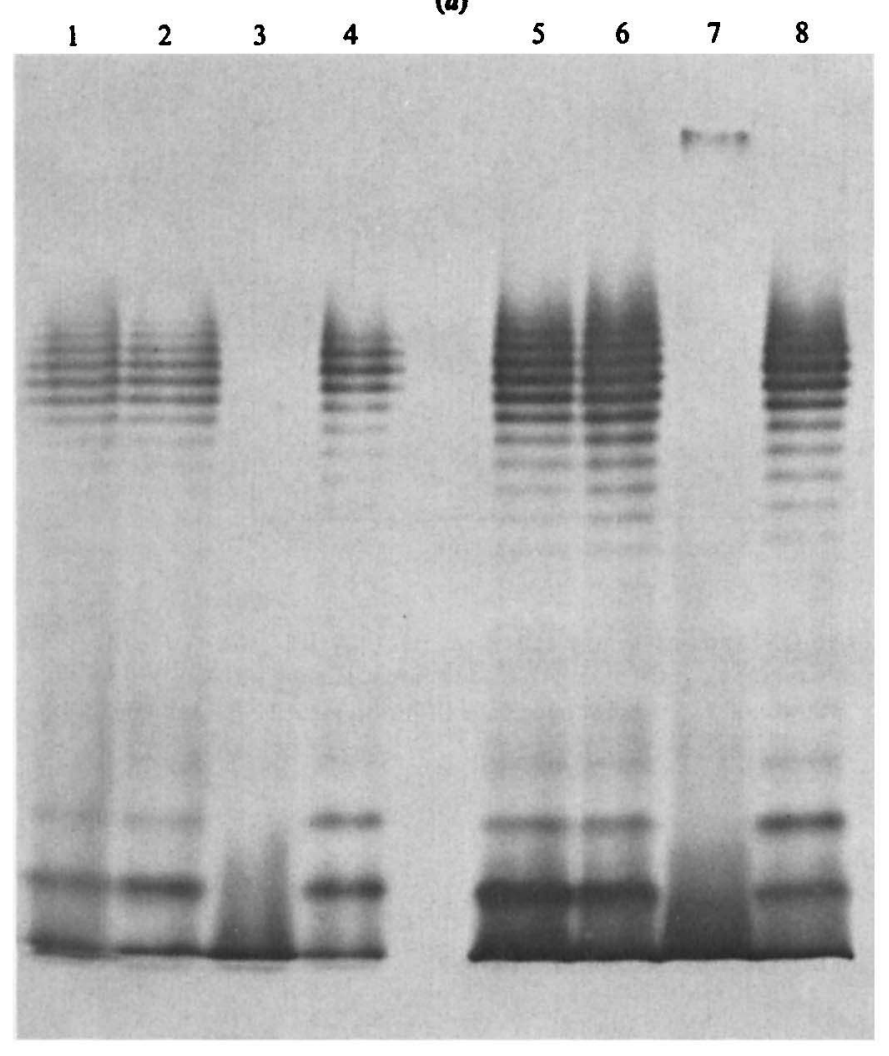

(b)

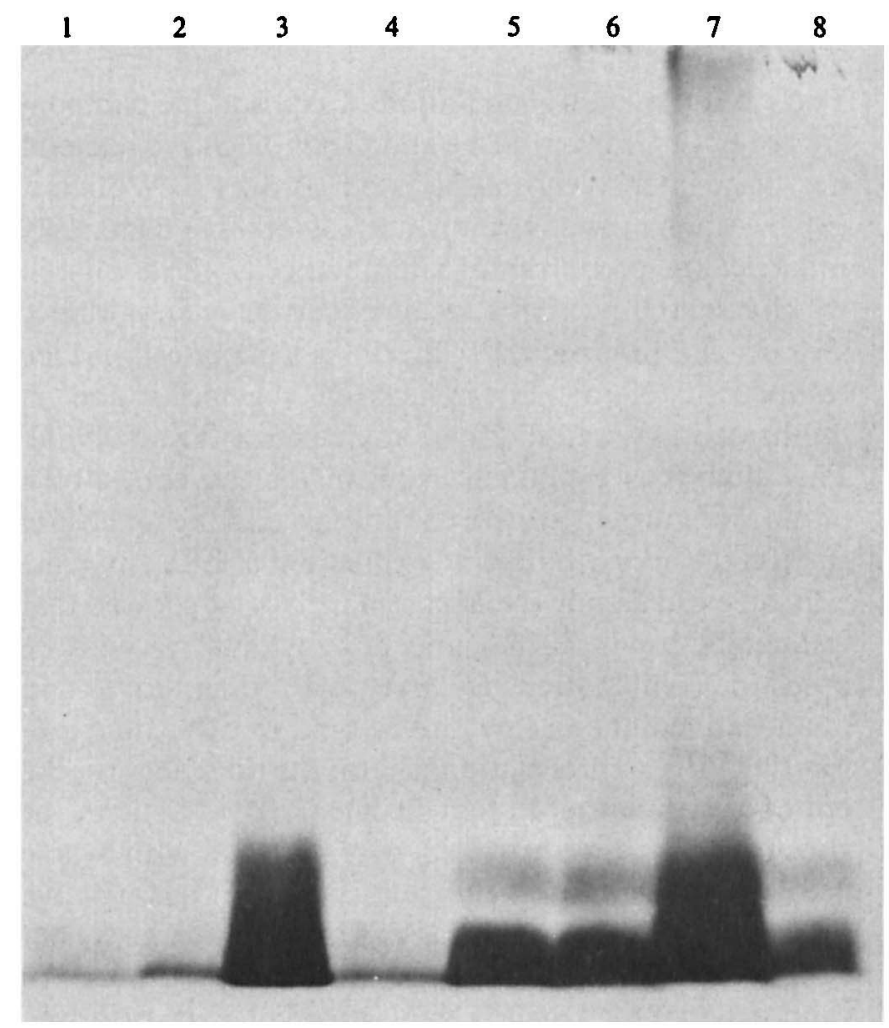

Fig. 3. (a) Silver-stained LPS profiles of proteinase K whole cell digests of four $E$. coli strains $(\mathrm{O} 18: \mathrm{K} 1$, $\mathrm{O} 18: \mathrm{K}^{-}, \mathrm{O} 18: \mathrm{Krf}$ and $\mathrm{O6}: \mathrm{K} 5$ ), separated by PAGE $(14 \%, w / v$, acrylamide). $(b, c)$ Immunoblots of the four $E$. coli strains transferred to nitrocellulose paper and probed with two core-specific mAbs, C-1 $(b)$ and C-2 (c). Tracks 1-4 and 5-8 represent the four E. coli strains grown to early stationary phase in nutrient broth and heat-inactivated sheep serum respectively.

(c)

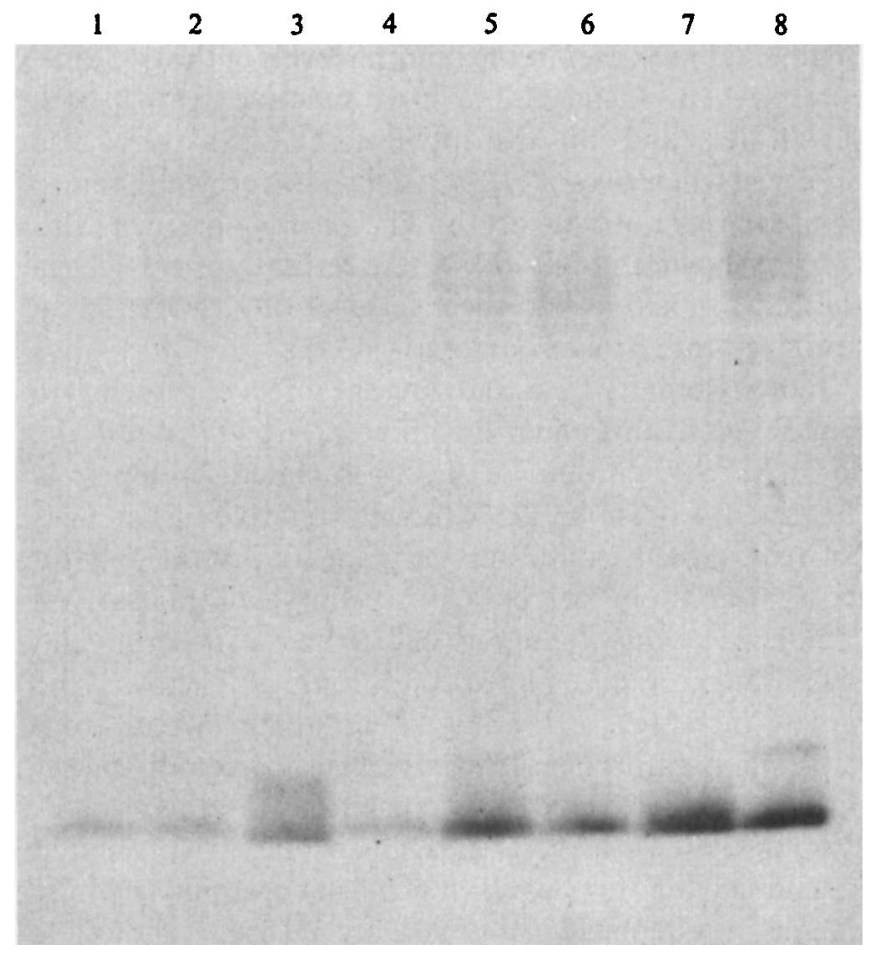




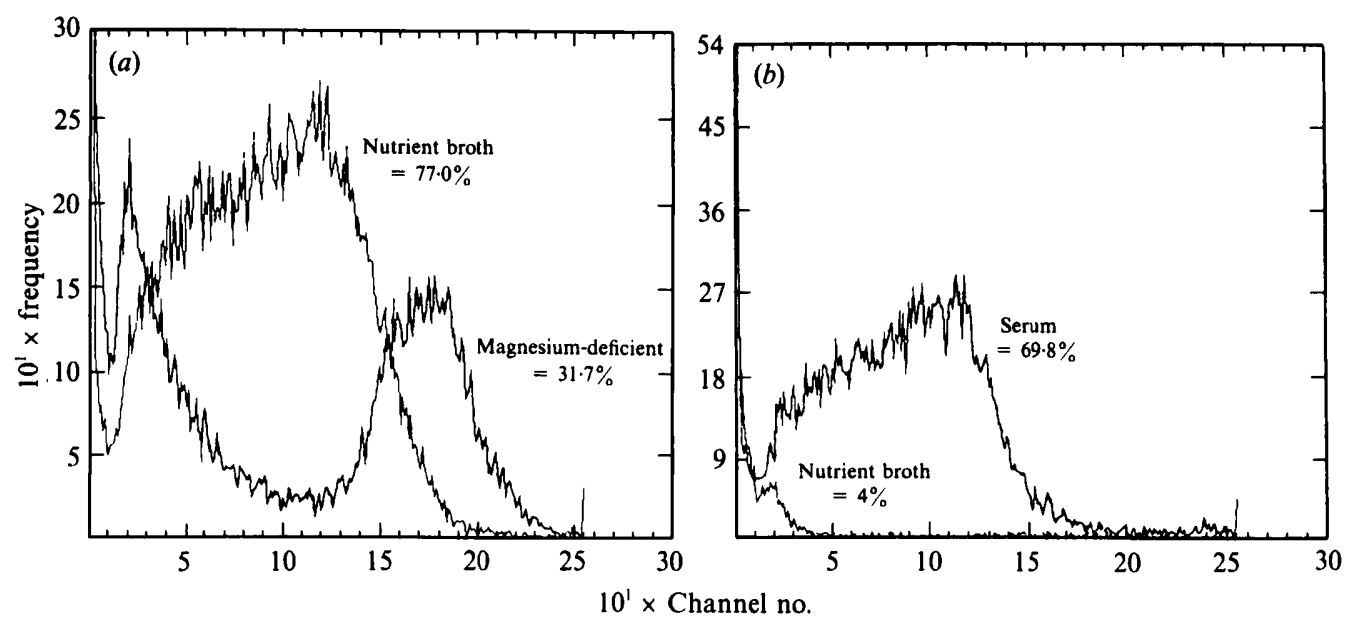

Fig. 4. Green fluorescence intensity histograms of (a) the anti-O18 mAb (O-1) against whole cells of $E$. coli $\mathrm{O} 18: \mathrm{K} 1$ grown to early stationary phase in nutrient broth and in a magnesium-depleted medium and $(b)$ an anti-core mAb $(\mathrm{C}-1)$ against $E$. coli $\mathrm{O} 18: \mathrm{K}^{-}$grown in nutrient broth and in a heat-inactivated sheep serum medium. Percentage values represent bacteria exhibiting positive fluorescence above background levels.

observed. The biphasic fluorescence pattern produced by magnesium-depleted cells demonstrated the presence of two distinct subpopulations of $E$. coli $\mathrm{O} 18: \mathrm{K} 1$ on the basis of differential binding by $\mathrm{mAb}$ O-1. Probing the same cells with $C-1$, a mAb reactive against unsubstituted core LPS, resulted in positive fluorescence levels of $3 \%$ for nutrient broth and $21 \%$ for magnesium depletion. Significant increases in the binding levels of the two anticore $\mathrm{mAbs} \mathrm{C}-1$ and $\mathrm{C}-2$ (a mAb reactive against both substituted and unsubstituted core LPS) were also observed when $E$. coli $\mathrm{O} 18: \mathrm{K}^{-}$cells were grown in serum compared to nutrient broth. The results obtained with $\mathrm{C}-1$ are shown in Fig. 4(b), where serum-grown bacteria showed a positive fluorescence level $66 \%$ higher than nutrient-broth-grown bacteria.

Flow cytometry data, showing the effect of growing all four $E$. coli strains under the different growth conditions on $\mathrm{mAb}$ recognition of LPS-associated epitopes is presented in Table 2. Although relative differences between growth conditions remained constant, day-today variation in percentage labelling within a given sample was evident. Smooth cells grown with serum and under magnesium-depleted conditions again showed the largest increases in binding of anti-core mAbs. Irondepleted and nitrogen deficient cells showed only minor differences compared to nutrient-broth-grown cells. Probing cells with the $\mathrm{O}$-antigen-specific mAb resulted in similar binding levels for most conditions, whilst magnesium-depleted cells, notably $018: \mathrm{K}^{-}$showed a significant decrease. Enhanced binding of the two anticore mAbs, especially $\mathrm{C}-1$, was observed against the rough mutant $\mathrm{O} 18: \mathrm{Krf}$, compared to the smooth strains. Minor variations between growth conditions of $\mathrm{O} 18: \mathrm{Krf}$ cells reacted with anti-core $\mathrm{mAbs}$ favoured higher percentage labelling for bacteria grown in magnesiumdepleted conditions.

\section{Discussion}

The environmental modulation of cell surface components of both Gram-positive and Gram-negative bacteria has been intensively investigated (Brown \& Williams, 1985). Among the environmental factors that commonly influence the properties of microbial cells, the availability of essential nutrients assumes particular importance (Harder \& Dijkhuizen, 1983). LPS is a major cell surface component of all Gram-negative bacteria, and is implicated as a cause of endotoxic shock (Ryan, 1985). This study has examined using mAbs the effects of a number of nutrient growth conditions, relating to those in vivo, on the accessibility and expression of LPS antigens.

In an earlier study (Nelson et al., 1990) we showed that immunoblotting, ELISA and flow cytometry could be used in combination to give both qualitative and quantitative data on how mAbs bind to LPS. Immunoblotting gives information as to the location of the epitope within the LPS molecule: viz. O-antigen, or substituted or unsubstituted core. ELISA with whole cells gives an extremely sensitive and quantitative indication of the binding of mAbs to whole cells, but suffers from the disadvantage that the procedure for immobilizing the bacteria to plastic may have distorting influences on the cells which may change binding characteristics. Flow cytometry lacks the sensitivity and 
automation of ELISA but is quantitative and the binding occurs in physiological conditions.

The results presented in the current study indicate that the expression of $E$. coli core LPS increases when grown in magnesium-depleted conditions $\left(0.17 \mathrm{mmol} \mathrm{l}^{-1}\right.$, cf. $0.65-1.0 \mathrm{mmol}^{-1}$ in serum). This was reflected in greater binding of anti-core mAbs in whole cell ELISA and flow cytometry, and this was supported by PAGE and immunoblotting. Magnesium is important in maintaining the stability of the structural arrangement of larger molecules such as LPS within the outer membrane of Gram-negative bacteria (Costerton et al., 1974). Cell walls of magnesium-limited cells of Bacillus subtilis show an increased $\mathrm{Mg}^{2+}$-binding affinity over magnesiumsufficient cells (Meers \& Tempest, 1968). Thus, certain organisms may respond to magnesium limitation by improving their ability to bind the ions by increasing negatively charged cell surface components such as LPS. Using both batch and continuous culture Day \& Marceau-Day (1982), also reported compositional changes in Pseudomonas aeruginosa LPS in response to $\mathrm{Mg}^{2+}$ concentration, reflecting functional alterations in the LPS. Data indicated a change in core size of LPS relative to the $\mathrm{O}$-antigen component, suggesting the possibility of magnesium having a regulatory role on one or more of the LPS biosynthetic enzymes. An increased production of low molecular mass LPS was seen for $E$. coli grown at intermediate growth rates under magnesium limitation (Dodds et al., 1987). The amino-sugar, 2aminohexose was also found to be absent from the $\mathrm{O}$ polysaccharide. Flow cytometric analysis of $E$. coli O18:K1 grown under magnesium-depleted conditions and probed with an $\mathrm{O}$-antigen specific $\mathrm{mAb}$ revealed two populations of bacteria. Possible reasons for this include: differences in the structure or amount of LPS; the amount of capsule [shown to be inhibited under these conditions by Taylor et al. (1981)]; or morphological heterogeneity of bacteria grown under magnesiumdepletion. The composition of LPS from E. coli $\mathrm{O} 18$ : $\mathrm{K}^{-}$ LPS was shown to differ from nutrient-broth-grown LPS using nuclear magnetic resonance spectrometry (unpublished data). As well as a decrease in the amount of $\mathrm{O}$ polysaccharide, rhamnose, a constituent of the $\mathrm{O} 18 \mathrm{O}$ antigen, was found to be replaced by an as yet unidentified sugar.

The low availability of iron is acknowledged as a key determinant of virulence (Griffiths, 1987). Alterations in the outer membrane of many bacterial species under conditions of iron-deprivation include the production of high molecular mass, iron-regulated outer-membrane proteins (Neilands, 1982). Little effect of iron depletion on LPS production was observed by silver-staining and immunoblotting. However, increasing the degree of iron deprivation led to a greater expression of rough core at the expense of high molecular mass O-polysaccharide LPS (data not shown). Indeed, binding of anti-core mAbs to whole cells was shown to improve by whole cell ELISA (Table 1), although not significantly using flow cytometry (Table 2). This may be partly explained by differences in the two techniques for, as discussed above, ELISA is prone to distortions not present in flow cytometry, possibly leading to improved accessibility of antibodies to LPS epitopes. Although changes in the expression of LPS per se have been illustrated, growth under stress conditions such as iron or magnesium deficiency is likely to alter the structure and composition of other components of the outer membrane. Therefore, LPS core determinants normally showing limited accessibility may become better exposed on the cell surface. Although this study attempted to assess the binding of anti-LPS mAbs to whole cells, release of membrane fragments from cells must also be considered. Indeed, variations in growth conditions could alter the extent and nature of the excretion of such fragments (Hoekstra et al., 1976).

The present findings also show a significant increase in binding of anti-core mAbs when smooth $E$. coli, especially the non-capsulate $018: \mathrm{K}^{-}$, were grown in heat-inactivated sheep serum. Immunoblotting, ELISA and flow cytometry all showed marked increases in binding of $\mathrm{mAbs}$ to the core region, despite an apparent increase in the expression of O-antigen as revealed by silver staining. The possible presence of endogenous anti-LPS antibodies within the serum may have caused a false impression of $\mathrm{mAb}$ binding. However, since mAbs were raised in a species different from that in which the serum was obtained, antibody conjugates might be expected to recognize only mouse mAbs. Also, removal of any anti-LPS antibodies from the serum by absorption with bacteria had no effect on the results (data not shown). Thus heat-inactivated sheep serum appears to alter the antigenic expression of LPS to permit binding of $\mathrm{mAbs}$ to the core region. Chedid et al. (1968) proposed an enzymic process within serum capable of attacking cell wall components, thereby unmasking the conserved rough antigenic structures.

Although capsule plays an important role in the serum resistance of many bacteria (Leying et al., 1990), it has been reported not to provide a barrier function for binding of anti-O antibodies to Klebsiella (Williams et $a l ., 1988$ ) and some $E$. coli strains including $O 18$ (Cross et al., 1986). Indeed, binding of the anti-O18 $\mathrm{mAb}$ to capsulate and non-capsulate strains of E. coli $\mathrm{O} 18$ showed no effect due to the presence of capsule. However, greater binding of anti-core $\mathrm{mAbs}$ to the noncapsulate strain indicates capsules may have a function as a barrier for the penetration of anti-core LPS antibodies. Growth under nitrogen-deficient/high-car- 
bon conditions has been shown previously to promote capsule formation (Sutherland \& Wilkinson, 1965). Reduced binding of anti-core mAbs to both capsulate and non-capsulate bacteria grown under these conditions suggested another factor, other than capsule exerting an influence. Indeed, an observed increase in chain length and production of $\mathrm{O}$-polysaccharide was revealed by silver staining and immunoblotting (Fig. 1). Since Opolysaccharide is known to reduce accessibility to core LPS (Gigliotti \& Shenep, 1985), a change in both its production and possible arrangement may have strengthened this effect. A variety of growth conditions have been shown to alter the expression of O-antigenic LPS molecules. McGroarty \& Rivera (1990) demonstrated a very marked decrease in the length of the O-specific LPS of cells grown under a number of stress conditions, whilst growth phase (Day \& Marceau-Day, 1982) and growth rate (Dodds et al., 1987) also influence its expression. Such variability in the expression of LPS polysaccharide formation may contribute towards the ability of bacteria to adapt to changes in the environment. Since variables other than nutrient limitation influence the expression of LPS, it is acknowledged that in using the batch culture model, the significance of altering one variable cannot be divorced with certainty from the influence of others.

We are grateful to Robin Barclay and colleagues at the S.E. Scotland Blood Transfusion Service for their on-going interest and collaboration in the project and their help in the selection of the monoclonal antibodies. Keith James and colleagues of the Surgery Department, University of Edinburgh are thanked for performing the fusions and producing the mAb supernates. We thank Bill Neill of the Department of Medical Microbiology for tirelessly and skilfully operating the flow cytometer. The work described here was funded by Sandoz, Basel, Switzerland and we thank Franco di Padova and Max Schreier for their help and encouragement.

\section{References}

Aydintung, M. K., Inzana, T. J., Letonja, T., Davis, W. C. \& CORBEIL, L. B. (1989). Cross-reactivity of monoclonal antibodies to Escherichia coli J5 with heterologous Gram negative bacteria and extracted lipopolysaccharides. Journal of Infectious Diseases 160 , 846-857.

Brown, M. R. W. \& Williams, P. (1985). The influence of environment on envelope properties affecting survival of bacteria in infections. Annual Review of Microbiology 39, 527-556.

Chedid, L., Parant, M., Parant, F. \& Boyer, F. (1968). A proposed mechanism for natural immunity to enterobacterial pathogens. Journal of Immunology 100, 292-301.

Chia, S. K. S., Pollack, M., Guelde, G., Koles, N. L., Miller, M. \& Evans, M. E. (1989). Lipopolysaccharide(LPS)-reactive monoclonal antibodies fail to inhibit LPS-induced tumor necrosis factor secretion by mouse-derived macrophages. Journal of Infectious Diseases 159, 872-880.

Costerton, J. W., Ingram, J. M. \& Chang, K. J. (1974). Structure and function of the cell envelope of Gram-negative bacteria. Bacteriological Reviews 38, 87-110.

Cross, A. S., Kim,, K. S., Wright, D. C., SAdoff, J. C. \& Gemski, P. (1986). Role of lipopolysaccharide and capsule in serum resistance of bacteremic strains of Escherichia coli. Journal of Infectious Diseases 154, 497-503.

Day, D. F. \& Marceau-Day, M. L. (1982). Lipopolysaccharide variability in Pseudomonas aeruginosa. Current Microbiology 7, 93-98.

DodDs, K. L., PerRY, M. M. \& MCDonalD, I. J. (1987). Alterations in the lipopolysaccharide produced by chemostat-grown Escherichia coli $\mathrm{O} 157: \mathrm{H} 7$ as a function of growth rate and growth-limiting nutrient. Canadian Journal of Microbiology 33, 452-458.

Dunn, D. L., Ewald, D. C., Chandan, N. \& Cerra, F. B. (1986). Immunotherapy of Gram negative bacterial sepsis. Archives of Surgery 121, 58-62.

GIGLIOTTI, F. \& SHENEP, J. L. (1985). Failure of monoclonal antibodies to core glycolipid to bind intact smooth strains of Escherichia coli. Journal of Infectious Diseases 151, 1005-1011.

GRIFFITHS, E. (1987). The iron uptake systems of pathogenic bacteria. In Iron and Infection - Molecular, Physiological and Clinical Aspects, pp. 69-138. Edited by J. J. Bullen \& E. Griffiths. Chichester: John Wiley.

Hancock, I. C. \& Poxton, I. R. (1988). Bacterial Cell Surface Techniques. Chichester: John Wiley.

Harder, W. \& Dijkhuizen, L. (1983). Physiological responses to nutrient limitation. Annual Review of Microbiology 37, 1-23.

HeumanN, D., Baumgartner, J. D., Jacot-Guillarmod, H. \& Glauser, M. P. (1991). Antibodies to core lipopolysaccharide determinants: absence of cross-reactivity with heterologous lipopolysaccharide. Journal of Infectious Diseases 163, 762-768.

HitchCOCK, P. J. \& Brown, T. M. (1983). Morphological heterogeneity among Salmonella lipopolysaccharide chemotypes in silverstained polyacrylamide gels. Journal of Bacteriology 154, 269-277.

Hoekstra, D., Van der laAn, J. W., De LeiJ, L. \& Wit, B. (1976). Release of outer membrane fragments from normally growing Escherichia coli. Biochimica et Biophysica Acta 455, 889-899.

De Jongh-Leuvenink, J., Schellekens, J. \& Verhoef, J. (1990). Characterization of anti-core glycolipid monoclonal antibodies with chemically defined lipopolysaccharides. Infection and Immunity 58, 42l-426.

Kelly, N. M., Bell, A. \& Hancock, R. E. W. (1989). Surface characteristics of Pseudomonas aeruginosa grown in a chamber implant model in mice and rats. Infection and Immunity 57, 344-350.

KIPPS, T. J. \& HERTZENBERG, L. A. (1986). Schemata for production of monoclonal antibody-producing hybridomas. In Handbook of Experimental Immunology, pp. 108.1-108.9. Edited by D. M. Weir. Oxford: Blackwell.

LAEMMLI, U. K. (1970). Cleavage of structural proteins during the assembly of the head of bacteriophage T4. Nature, London 227, 680685 .

Leying, H., Suerbaum, S., Kroll, H-P., Stahl, D. \& Opferkuch, W. (1990). The capsular polysaccharide is a major determinant of serum resistance in K-1-positive blood culture isolates of Escherichia coli. Infection and Immunity 58, 222-227.

MCGroARTY, E. J. \& Rivera, M. (1990). Growth-dependent alteration in production of serotype-specific and common antigen lipopolysaccharides in Pseudomonas aeuruginosa PAO1. Infection and Immunity 57, 1030-1037.

MAYORAL, J. L. \& DunN, D. L. (1990). Cross-reactive murine monoclonal antibodies directed against the core/lipid A region of endotoxin inhibit production of tumor necrosis factor. Journal of Surgical Research 49, 287-292.

MEERS, J. L. \& TEMPEST, D. W. (1968). The influence of extracellular products on the behaviour of mixed microbial populations in magnesium-limited chemostat cultures. Journal of General Microbiology 52, 309-317.

Morse, S. A., Mintz, C. S., Sanfia, S. K., Bauertenstein, L., Bortram, M. \& ARCELla, M. A. (1983). Effect of dilution rate on lipopolysaccharide and serum resistance of Neisseria gonorrhoeae grown in continuous culture. Infection and Immunity 41, 74-82.

NEILANDS, J. B. (1982). Microbial envelope proteins related to iron Annual Review of Microbiology 36, 285-309.

Nelson, D., Neill, W. \& Poxton, I. R. (1990). A comparison of immunoblotting, flow cytometry and ELISA to monitor the binding of anti-lipopolysaccharide monoclonal antibodies. Journal of Immunological Methods 133, 227-233. 
Pollack, M., Chia, J. K. S., Koles, N. L., Miller, M. \& Guelde, G. (1989). Specificity and cross-reactivity of monoclonal antibodies reactive with core and lipid A regions of bacterial lipopolysaccharide. Journal of Infectious Diseases 159, 168-184.

Robert-Gero, M., Poiret, M. \& Cohen, G. N. (1970). The aspartate kinase of Pseudomonas putida, regulation of synthesis and activity. Biochimica et Biophysica Acta 206, 17-30.

RYAN, J. L. (1985). Microbial factors in pathogenesis: lipopolysaccharides. In Septic Shock (Contemporary Issues in Infectious Diseases), pp. 13-25. Edited by K. Root \& M. A. Sande. New York: Churchill Livingstone.

SCOTT, B. B. \& BaRClay, G. R. (1987). Endotoxin-polymyxin complexes in an improved enzyme-linked immunosorbent assay for IgG antibodies in blood-donor sera to Gram-negative endotoxin core glycolipids. Vox Sanguinis 52, 272-280.

Smith, A. W., Wilton, J., Clark, S. A., Alpar, O., Melling, J. \& Brown, M. R. W. (1991). Production and characterization of monoclonal antibodies to outer membrane proteins of Pseudomonas aeruginosa grown in iron depleted media. Journal of General Microbiology 137, 227-236.

Sutherland, I. W. \& Wilkinson, J. F. (1965). Depolymerases for bacterial exopolysaccharides obtained from phage-infected bacteria. Journal of General Microbiology 39, 373-383.
TAYLOR, P. W., MESSNER, P. \& PARTON, R. (1981). Effect of the growth environment on cell-envelope components of Escherichia coli in relation to sensitivity to human serum. Journal of Medical Microbiology 14, 9-19.

Terry, J. M., Pina, S. E. \& Mattingly, S. J. (1991). Environmental conditions which influence mucoid conversion in Pseudomonas aeruginosa PAO1. Infection and Immunity 59, 471-477.

Towbin, H., Staehelin, T. \& GoRDON, J. (1979). Electrophoretic transfer of proteins from polyacrylamide gels to nitrocellulose sheets: procedure and some applications. Proceedings of the National Academy of Sciences of the United States of America 76, 4350-4354.

TSAI, C.-M. \& FrasCh, C. E. (1982). A sensitive silver stain for detecting lipopolysaccharide in polyacrylamide gels. Analytical Biochemistry 119, 115-119.

Williams, P., Lambert, P. A. \& Brown, M. R. W. (1988). Penetration of immunoglobulins through the Klebsiella capsule and their effect on cell-surface hydrophobicity. Journal of Medical Microbiology 26, 29-35.

Ziegler, E. J., Fisher, C. J., Sprung, C. L., Straube, R. C., Sadoff, J. C., FoulKe, G. E. \& Wortel, C. H. (1991). Treatment of Gramnegative bacteremia and septic shock with HA-IA human monoclonal antibody against endotoxin. New England Journal of Medicine 324, 429-436. 